\title{
Recent patent applications in biomedical imaging
}

\begin{tabular}{|c|c|c|c|c|c|}
\hline Patent number & Description & Assignee & Inventor & $\begin{array}{l}\text { Priority } \\
\text { application } \\
\text { date }\end{array}$ & $\begin{array}{c}\text { Publication } \\
\text { date }\end{array}$ \\
\hline WO 2013122710 & $\begin{array}{l}\text { A method for analyzing vascular permeability and flow } \\
\text { in human body using biomedical images, involving } \\
\text { determining pharmacokinetic parameter value based on } \\
\text { the application of a linear least squares fitting } \\
\text { algorithm to a linear model. }\end{array}$ & $\begin{array}{l}\text { Arizona Board of Regents } \\
\text { (Tucson) }\end{array}$ & $\begin{array}{l}\text { Cardenas-Rodriguez J, } \\
\text { Pagel MD }\end{array}$ & $2 / 13 / 2012$ & $8 / 22 / 2013$ \\
\hline US 20130208737 & $\begin{array}{l}\text { A variable repetition rate and wavelength optical pulse } \\
\text { source for imaging applications that enables the source } \\
\text { of supercontinuum pulses and optical bandpass filter to } \\
\text { provide variable repetition rate and variable wavelength } \\
\text { optical pulses. }\end{array}$ & $\begin{array}{l}\text { Clowes JR, Godfrey IM, } \\
\text { Grudinin AB }\end{array}$ & $\begin{array}{l}\text { Clowes JR, Godfrey IM, } \\
\text { Grudinin AB }\end{array}$ & $1 / 19 / 2008$ & $8 / 15 / 2013$ \\
\hline US 20130188241 & $\begin{array}{l}\text { An optical pulse source for generating optical } \\
\text { supercontinuum pulses for, e.g., biomedical imaging } \\
\text { application; has an optical fiber in which optical pump } \\
\text { pulses are launched without the use of free space } \\
\text { optics. }\end{array}$ & $\begin{array}{l}\text { Clowes JR, Godfrey IM, } \\
\text { Grudinin AB }\end{array}$ & $\begin{array}{l}\text { Clowes JR, Godfrey IM, } \\
\text { Grudinin AB }\end{array}$ & $1 / 19 / 2007$ & $7 / 25 / 2013$ \\
\hline WO 2013088144 & $\begin{array}{l}\text { A method for transforming a biomedical image of a } \\
\text { heart, involving calculating a transform value indica- } \\
\text { tive of a voxel for representing a tissue type for each } \\
\text { voxel of a biomedical image and calculating the clinical } \\
\text { indicator from the voxel value of the extracted image } \\
\text { segment. }\end{array}$ & $\begin{array}{l}\text { Gardiner S, University } \\
\text { of Stavanger (Stavanger, } \\
\text { Norway), Stavanger } \\
\text { University Hospital } \\
\text { (Stavanger, Norway) }\end{array}$ & $\begin{array}{l}\text { Eftestol T, Engan K, } \\
\text { Kotu LP, Orn S, Woie L }\end{array}$ & $12 / 12 / 2011$ & $6 / 20 / 2013$ \\
\hline WO 2013078244 & $\begin{array}{l}\text { A new rhodamine-type compound used, e.g., as a } \\
\text { fluorescent dye, in medical diagnostics and for labeling } \\
\text { a protein for quantification of protein interactions and } \\
\text { detecting the presence of an enzyme in a sample. }\end{array}$ & $\begin{array}{l}\text { Promega (Madison, WI, } \\
\text { USA) }\end{array}$ & $\begin{array}{l}\text { Dwight S, Kirkland TA, } \\
\text { McDougall MG }\end{array}$ & $11 / 21 / 2011$ & $5 / 30 / 2013$ \\
\hline CN 102951642 & $\begin{array}{l}\text { A method for preparing water-soluble nano-silicon } \\
\text { particles, comprising carrying out an electrochemical } \\
\text { corrosion of a monocrystalline silicon sheet to obtain } \\
\text { a porous silicon sheet and mixing the sheet in organic } \\
\text { solvent; useful, e.g., for biomedical imaging. }\end{array}$ & $\begin{array}{l}\text { Changzhou Nuoruige } \\
\text { Nanotechnology } \\
\text { (Changzhou, China) }\end{array}$ & Chao Y & $8 / 31 / 2011$ & $3 / 6 / 2013$ \\
\hline CN 102925160 & $\begin{array}{l}\text { A method of synthesizing gold-doped fluorescent } \\
\text { quantum dots used for biomedical imaging and } \\
\text { biological analysis, comprising reacting, e.g., potassium } \\
\text { borohydride and tellurium powder and adding, e.g., } \\
\text { water-soluble cadmium salt and gold compound. }\end{array}$ & $\begin{array}{l}\text { Zhejiang University } \\
\text { (Hangzhou, China) }\end{array}$ & Han S, Jin W, Mu Y & $1 / 8 / 2010$ & $2 / 13 / 2013$ \\
\hline WO 2013116322 & $\begin{array}{l}\text { A method for generating thermo-acoustic signals for } \\
\text { thermo-acoustic tomography and hyperthermia, } \\
\text { involving receiving an ultrasonic signal from the region } \\
\text { imbued with magnetic particles generated by particles } \\
\text { under a pulsed magnetic field. }\end{array}$ & $\begin{array}{l}\text { Oklahoma State } \\
\text { University (Stillwater, OK, } \\
\text { USA) }\end{array}$ & Piao D & 1/30/2012 & $1 / 30 / 2013$ \\
\hline
\end{tabular}

